\title{
POLITICAL ONTO-THEOLOGIES OR TOWARDS A POLITICAL METAPHYSICS. SOME CRITICAL ANALOGIES FROM PLATO TO JÜRGEN MOLTMANN
}

\author{
Prof. Ph.D. Spiros MAKRIS, \\ Assistant Professor in Political Theory, University of Macedonia, Thessaloniki, GREECE, \& \\ Visiting Scholar, CAPPE, School of Humanities, University of Brighton, \\ Email:smakris@uom.gr
}

\begin{abstract}
The fruitful revival of political onto-theology in the 20th century, just in the heart of the so-called Weimar Renaissance, is connected not only with the revised image of the Middle Ages, but also with the total recall of the problem evil in the epicenter of late modernity, due to the bloody and barbaric World Wars. Both New Political Theology and post-fundamental political onto-theologies, in the sense of a radical onto-theologia negativa, brought to the forefront of contemporary social, political and ethical theory the essential issues of ontological, theological and moral interpretation of the political. It is not by accident that New Political Theology comes to the postwar theoretical and experiential scene as a rival against Schmittian political theology. Now, the focal point of analysis is not political power, in the sense of state sovereignty, but a radical return to the forgotten theologian principles of Christology and Trinitarianism. As far as New Political Theology is concerned, the new content of political theology pursues more the republican and democratic aspects of a Crucified God on the Cross next to Jesus Christ, the poor and the pariahs. It is no coincidence that Moltmannian theology of hope is seen, in the final analysis, as a political theologia crucis. It is important to add that a significant role in the non-Schmittian political theology of the 20th century plays the messianic and/or apocalyptic Jewish political theology with apparent Marxist connotations and strong links with Critical Theory.
\end{abstract}

Keywords: political onto-theology; Plato; Jürgen Moltmann; pluralism;

\section{ARCHETYPAL ONTO-THEOLOGIES: FROM PLATO TO HEIDEGGER}

Plato is the founder of political onto-theology. He exemplifies the whole thing of political onto-theology with the famous allegory of the cave. Actually, the Platonic cave is the city; the republic; the polis. Within Platonic metaphysics, which is mainly represented in Plato's famous work Republic (in Greek: Пo $\lambda v \tau \varepsilon i \alpha)^{1}$, the cave is regarded as the place of politics. Citizens approach onto-theological truth only as shadow. The onto-theological foundation of politics, i.e. the political, is situated outside cave in the Platonic outer land of The Good (in Greek: To A $\gamma \alpha \theta$ ó). Only the philosopher (-king) can approach the outer land of real onto-theological truth. Undoubtedly, this is a dangerous voyage as all space trips are. It

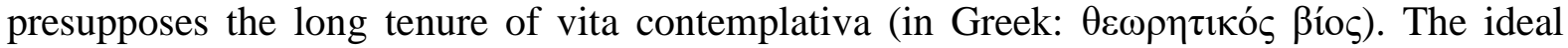
philosopher or the ideal mediator between the faulty reality of the city shades and the

\footnotetext{
${ }^{1}$ Plato, Republic, Dover Thrift Editions, United States, 2000 (Translated by Benjamin Jowett).
} 
authentic onto-theological reality of 'The Good' is Socrates himself. But when Socrates returns to the polis from this risky travel in the outer land of onto-theological foundation people lead him straight to death. They do not want to listen to the philosophical truth ${ }^{2}$. They prefer to live in the cave just being surrounded by flashing shadows. Platonic political ontotheology is marked by Plato's trauma. Since then, every political onto-theology in the longterm Western Tradition of political thought has been stigmatized by the traumatic and tragic death of Socrates.

St. Augustine is the Plato of the Christian Age. St. Augustine adopts the Platonic allegory of the cave for the sake of Christianity. He builds a Christian-led political ontotheology by dividing the entire universe into two cities: i) a City of God, i.e. the ontotheological foundation or the so-called 'the political', and ii) an Earthly City, i.e. the city in the meaning of politics ${ }^{3}$. Once more, the real epicenter of the universe is located outside of the Platonic cave. The real life is situated in an outer land so far away from the human faulty reality. Instead of Socrates, Christian theology puts Jesus Christ as the ideal mediator between City of God and Earthly City. But unfortunately, as in the tragic case of Socrates, Jesus has the same deadly fate as Socrates had before him. He dies on the Holy Cross as a humiliated Crucified God ${ }^{4}$. Since then, every Western political onto-theology is definitely haunted by the death of Jesus. Christianity's trauma is the tragic and brutal end of Jesus. The citizens of Earthly City do not want to listen to the truth coming from the City of God. They prefer to live in the Platonic cave among flashing shadows and distorted images.

$\left(1^{\text {st }}\right.$ CRITICAL NOTE) Following in Marx's footsteps, as he did with Hegel, Hannah Arendt makes a critical reverse in the political onto-theology of Western Tradition. She puts Augustine's feet back on the ground. Actually, she prioritizes the Earthly City against the City of God. In Latin terms, she brings to light amor mundi instead of amor Dei. In this vein, she builds a republican or Aristotelian-driven political onto-theology in which the truth is situated within the city walls and the critical holder and/or mediator of it is the thoughtful and responsible citizen itself (see Aristotelian phronesis) ${ }^{5}$.

Western onto-theology is based on two spiritual pillars. On the one hand is the Platoinspired transcendence of St. Augustine. In this sort of theology, the foundation of the world is situated in an outer holly land, i.e. City of God. Within the theoretical ranks of Augustinian onto-theology dominates the pure metaphysics of God. On the other hand is the ontotheology of Apostle Paul ${ }^{6}$. In this case, onto-theology of transcendence is transformed into onto-theology of immanence. The center of gravity is transferred towards the side of Jesus Christ himself. Apostle Paul, who is actually the founder of the Christian Church, perceives the body of Jesus Christ as the body of the Church itself. The immanence of Corpus Christi puts Earthly City in the heart of the world. The holy land is no longer the City of God but the

\footnotetext{
${ }^{2}$ Plato, Five Dialogues, Hackett Publishing Company, Inc., United States of America, 2002, p. 21 (Translated by G. M. A. Grube).

${ }^{3}$ Saint Augustine, City of God, Random House, Inc., New York, 1958

${ }^{4}$ J. B. Phillips, The New Testament in New English (Revised Edition), Touchstone Book, New York, 1995.

5 Spiros Makris, "Aristotle in Hannah Arendt's Republicanism. From homo faber to homo politicus', In: Annuaire International Des Droits De L' Homme, Volume IX, 2015-2016, Issy-les-Moulineaux Cedex, Paris: L.G.D.J. lextensoéditions (2017), pp. 535-563 and Spiros Makris, 'Public sphere as 'ultimum refugium'. The philosophical, political and ethical theory of Hannah Arendt', In: International Journal of Theology, Philosophy and Science, Vol. 3, No. 4 (2019), pp. 77-92.

${ }^{6}$ E. P. Sanders, Paul. The Apostle's Life, Letters and Thought, Fortress Press, U.S.A., 2015 and Jacob Taubes, The Political Theology of Paul, Stanford University Press, Stanford, California, 2004 (Translated by Dana Hollander).
} 
Holy Cross. In fact, Pauline onto-theology is a theologia crucis. From the $12^{\text {th }}$ century, at the end of Middle Ages, until the Protestant Reformation, or the beginning of the Modernity, the onto-theology of Corpus Christi turns into the dominant political theory. Political power is divided into two bodies: i) a mortal body, that is represented from the dead King; ii) an immortal body, that is symbolized by the signifier of power itself. In the field of growing democratic theory, Corpus Christi is gradually transformed into the Corpus Mysticum (i.e. the Church as the mystical body of Christ) ${ }^{7}$. Since then, the immortal body of political power is identified with the body of democratic multitude.

$\left(2^{\text {nd }}\right.$ CRITICAL NOTE) Ernst Kantorowicz, the famous German-Jew political historian, who fled to the U.S. after the rise of Nazi in power in 1933, as did most of the greatest thinkers of the so-called Weimar era (1919-1933), scrutinizes and analyzes in-depth this critical reverse within the practical and theoretical process of the medieval political ontotheology ${ }^{8}$.

In 1789, when the body of Louis XVI is beheaded, Corpus Mysticum is turned into an empty place; and empty signifier. Since then, political onto-theology of democracy is realized, as Claude Lefort brilliantly claims, in the sense of an unstoppable and sometimes entirely tragic dissolution of the markers of certainty ${ }^{9}$. From then on, nothing can be taken for granted. All the traditional onto-theological foundations (e.g. God, State or King) have been ruined. This is the actual meaning of the famous painting of Paul Klee, once more from the Weimar era, that Walter Benjamin inspirationally transforms into the idea of political ontotheology of Angelus Novus. In fact, human history is regarded as a tragic course where the documents of civilization are actually documents of murderous barbarity ${ }^{10}$. In Shakespearean terms, in the words of Hamlet, the time is out of joint ${ }^{11}$. In Kantian lexicon, everything is possible now either radical good or radical evil ${ }^{12}$. The new holder of political power, the People itself, lives in a frenzy condition of absolute openness and emptiness. So, each time democracy moves towards its absolute closure, the (Freudian: see unheimlich) monster of Totalitarianism comes to the fore ${ }^{13}$. This is the well-known democratic paradox or the paradox of democratic immanence (i.e. Spinozian conatus) ${ }^{14}$.

$\left(3^{\text {nd }}\right.$ CRITICAL NOTE) Because of this entirely paradoxical character of democracy, Jacques Derrida determines democracy as the onto-theological field of a possible impossibility par excellence. In this paradoxical respect, democracy is seen by Derrida as a

\footnotetext{
${ }^{7}$ Henri Cardinal de Lubac SJ, Corpus Mysticum. The Eucharist and the Church in the Middle Ages, University of the Notre Dame Press, Notre Dame, Indiana, 2006 (Translated by Gemma Simmonds CJ with Richard Price and Christopher Stephens) and Ernst H. Kantorowicz, The King's Two Bodies. A Study in Medieval Political Theology, Princeton University Press, Princeton, New Jersey, 2016.

${ }^{8}$ Ernst H. Kantorowicz, The King's Two Bodies. A Study in Medieval Political Theology, Princeton University Press, Princeton, New Jersey, 2016.

${ }^{9}$ Claude Lefort, Democracy and Political Theory, Polity Press, Cambridge, 1988, p. 19 (Translated by David Macey) and Spiros Makris, "Democracy as a 'form of society'. Claude Lefort's post-foundational approach", In: 13th Conference of the European Sociological Association. (Un)Making Europe: Capitalism, Solidarities, Subjectivities. ESA 2017 Athens 29. 08 - 01. 09. Abstract Book, European Sociological Association, Hellenic Sociological Society, European Sociological Association, Paris, 2017, pp. 739-740.

${ }^{10}$ Walter Benjamin, Selected Writings, Volume 4, 1938-1940, Harvard University Press, U.S.A., 2016, p. 392.

${ }^{11}$ William Shakespeare, Hamlet, Simon \& Schuster Paperbacks, New York, 2012.

${ }^{12}$ Immanuel Kant, Religion within the Boundaries of Mere Reason and Other Writings, Cambridge University Press, Cambridge, 2018 (Translated by Allen Wood).

${ }^{13}$ Sigmund Freud, The Uncanny, Penguin Books, London, 2003 (Translated by David McLintock).

${ }^{14}$ Chantal Mouffe, The Democratic Paradox, Verso, London and New York, 2009 and Benedict de Spinoza, Ethics, Penguin Books, London, 1996 (Translated by Edwin Curley).
} 
spectrality or as an aporia (i.e. an irresolvable internal contradiction; or an unresolved question beyond the Hegelian Aufhebung*) that haunts our lives. In this specific regard, this democracy to come loses its traditional onto-theological attributes and is transformed into a hauntology (see from ontology to hauntology) ${ }^{15}$.

* In Hegelian philosophy Aufhebung is the process by which the conflict between two opposed or contrasting things or ideas is resolved by the emergence of a new idea, which both preserves and transcends them; in English: sublation/LEXICO Powered by Oxford (see Hegelian and thereby Marxian materialist dialectics of 'thesis, antithesis, synthesis' $)^{16}$.

It is commonplace that the end of Western metaphysics or, in other words, ontotheology is taking place within the oeuvre of the eminent German philosopher Martin Heidegger. For most of the specialists in the relevant field of Continental Philosophy, Heidegger and his work represent a strong venture for the radical deconstruction of Western onto-theology. Thus, it is no accident that the overwhelming majority of them claim that Martin Heidegger after Friedrich Nietzsche must be seriously perceived as the actual founder of postmodern philosophy; or discourse analysis; or philosophical hermeneutics ${ }^{17}$. In fact, the systematic critique of Western metaphysics within the fruitful Heideggerian thought chiefly concerns the challenge of Western foundationalism whether ontological or theological. More specifically, Martin Heidegger puts both onto-theological transcendence and immanence under question. Figuratively speaking, he transfers the onto-theological center of gravity far away from the Platonic outer land as well as the Platonic cave to a darkened and ambiguous place (it could be seen as something like the Freudian $I d$, i.e. unconscious physical energy or Spinozian conatus) exactly beneath the polis. If polis represents for Heidegger the metonymy of the political, then he draws further the origins of it beneath its visible and tangible foundations in a post-metaphysical place like Hades, which is actually an Abgrund, that is to say an abyss; a chaos; or a chasm $^{18}$. Thereby, it is no coincidence that Heidegger is seen as the 'patriarch' of post-foundational thought or even the radical trend of anti-foundationalism that under conditions may leads to a sort of post-metaphysical relativism, agnosticism or Nietzschean nihilism $^{19}$.

Actually, by radicalized Platonic realism through Medieval nominalism (see 'nomina nuda tenemus': we hold empty names), Heidegger brings to focus the linguistic, hermeneutic and rhetorical strength of Western philosophy in the sense of philosophizing or thinking. If the so-called linguistic turn from 1960s onwards could be traced in Heidegger's famous Kehre (i.e. turn), then contemporary philosophy is definitely hermeneutic venture ${ }^{20}$. In this specific vein, Heideggerian Abgrund must be seen as a philosophical endeavor opening up the (impossible: see here the Derridean reception of Heidegger in the case of the democracy to come) possibilities or the horizons of understanding creatively and freely the crucial question of the meaning of Being. In contemporary political onto-theology, Heidegger's influence is but enormous and continuous through different intellectual and spiritual

\footnotetext{
${ }^{15}$ Simon Morgan Wortham, The Derrida Dictionary, Continuum, London and New York, 2010, pp. 34-35.

${ }^{16}$ Georg Wilhelm Friedrich Hegel, The Phenomenology of Spirit, Cambridge, Cambridge University Press, 2018, pp. 69-70).

${ }^{17}$ John D. Caputo, Radical Hermeneutics, Indiana University Press, Bloomington and Indianapolis, 1987.

${ }^{18}$ Frank Schalow and Alfred Denker, Historical Dictionary of Heidegger's Philosophy (Second Edition), The Scarecrow Press, Inc., Lanham, Toronto, Plymouth, UK, 2010, p. 45.

19 Oliver Marchart, Post-Foundational Political Thought: Political Difference in Nancy, Lefort, Badiou and Laclau, Edinburgh University Press, Edinburgh, 2007, p. 11.

20 Richard E. Palmer, Hermeneutics. Interpretation Theory in Schleiermacher, Dilthey, Heidegger, and Gadamer, Northwestern University Press, Evanston, 1969.
} 
trajectories. The common denominator of this impact consists of the fact that Heideggerian Abgrund is conceived as the starting point of the so-called post-foundational or even antifoundational political thought. Even Cornelius Castoriadis, who seems to criticize, at first glance, Heideggerian philosophy, builds a sort of social ontology that approaches the preSocratic elements of Heidegger's theory about an abyssal foundation ${ }^{21}$.

In this regard, the political represents a kind of Platonic Khôra ${ }^{22}$; a chaotic field of almost impossible possibilities that give birth either to radical good or to radical evil. From this point of view, Friedrich Nietzsche must be regarded as the re-founder of contemporary post-metaphysical philosophy of Being. Thus, in a free translation and in a proportional manner, the question about political Being remains, in the last analysis, a critical and thorny question about the quintessence and the function of political metaphysics itself. Thus, I have coined this concept here in order to renter apparent the question of Political Being within the conceptual, epistemological and methodological framework of Western philosophy as a whole.

\section{LUTHERAN THEOLOGY AND POLITICAL ONTO-THELOGY}

\begin{tabular}{|c|c|}
\hline Deus absconditus & Theology of the Cross \\
\hline Deus: Absent. & Deus: Present. \\
\hline Topos: Darkness. & Topos: The light of passion on the Cross. \\
\hline Theology: Negative Theology or & Theology: Theologia crucis. \\
\hline Apophatic Theology in the terms of the & Key-concept: Immanence. \\
\hline Orthodox tradition. & Influences: Apostle Paul. \\
\hline Key-concept: Transcendence. & \\
\hline Influences: Plato and Dionysius the & \\
\hline Areopagite. & \\
\hline
\end{tabular}

Undoubtedly, one of the most thorny and conflictual questions in the long course of Western philosophical and theological tradition, that going through the tradition of political and ethical thought in the sense of political metaphysics or the hiddenness of Political Being (i.e. the question about the political foundation), is the question of deus absconditus ${ }^{23}$. Actually, the question of deus absconditus brings to the fore the critical question about the specific nature, the concrete name and ultimately the special topos (i.e. this hidden place) of God. From this point of view, onto-theology of God could be seen as an onto-theology of divine topos. Without doubt, the whole problématique is full of mystery and sui generis obscurantism. To put in a nutshell, it is like to try to fumble (or to trace or to detect) into the profound secrets of the divine itself ${ }^{24}$.

In fact, the topos of hidden God is darkness. Unquestionably, it is a topos beyond the human rationale or, in other words, the finite human logic. Martin Luther, who is apparently the great reformer (see Reformation) of Western onto-theology and thereby the actual founder of modern political onto-theology, claims that trying to construct an image of God is almost in vain. Thus, at the end of the day, theology of deus absconditus sounds like an ontotheology of divine topos or, to put it another way, an onto-theology regarding the special

\footnotetext{
${ }^{21}$ Suzi Adams, Castoriadis's Ontology. Being and Creation, Fordham University Press, New York, 2011,pp.4-5.

22 Jacques Derrida, On the Name, Stanford University Press, Stanford, California, 1995 (Translated by David Wood, John B. Leavey, Jr., and Ian McLeod), p. 89.

${ }^{23}$ Marius Timmann Mjaaland, The Hidden God. Luther, Philosophy, and Political Theology, Indiana University Press, Bloomington and Indianapolis, 2016.

${ }^{24}$ Marius Timmann Mjaaland, The Hidden God. Luther, Philosophy, and Political Theology, Indiana University Press, Bloomington and Indianapolis, 2016, pp. 87-100.
} 
place of God, if there is something like that. Drawing his inspiration from Dionysius the Areopagite (therefore here the whole thing is connected with Athenian democracy; Areopagus hill in Acropolis; and of course the apostle Paul himself whom Dionysius heard in Athens preaching the Word of God), Martin Luther initially identifies divine topos with darkness itself (that is to say this mysterious darkness that surrounds Jesus's passion on the Holy Cross and which is described almost poetically in the Gospel). It is worth noting that this paradoxical darkness during noon [see Good Friday] shocked the young Dionysius. Thereby, paraphrasing Heidegger, it could be claimed that God is hiding in-the-darkness. God is invisible and thus, in the final analysis, He remains an absolutely non comprehensible entity. His nature or His substance or His divine topos remains impassable from the finite human reason ${ }^{25}$.

As in Platonic metaphysics, God's divine topos is located beyond the human rationale (i.e. Plato's [allegory of the] cave). In this respect, theology of deus absconditus is entirely constructed as a negative theology (theologia negativa) or $^{26}$, in pure terms of Orthodox Christian tradition, an apophatic theology ${ }^{27}$. God is perceived as something negative. Actually, God is a negation. Aristotelian rules of logic are not enough to solve the question of God. Undoubtedly, theologia negativa must be regarded as a Mystical Theology ${ }^{28}$. Linguistically speaking, God's name (or Word stricto sensu) is a word without a real referent. It could be said that God is the archetypal symbol of empty signifier ${ }^{29}$. Poetically speaking, and paraphrasing here the Greek Nobel laureate poet George Seferis, God looks like an 'empty shirt', i.e. a shirt without a specific and tangible body (see real referent). God is the Hidden $\mathrm{One}^{30}$; an entity without a positive name that corresponds to a very tangible referent.

It is now easier to try to build a didactic analogy with the Political Being. In a proportional framework regarding negative political onto-theology, the name of the Political Being (i.e. the name of God in Derridean terms) must be seen as an empty signifier too; almost as an empty topos. Claude Lefort strongly claims that modern power (that is the image of political power since French Revolution) is an empty place $e^{31}$ and due to this critical ontotheological condition its paradoxical referent is democracy itself (the so-called democratic paradox according to Chantal Mouffe ${ }^{32}$; or democracy to-come in Jacques Derrida's lexicon $)^{33}$.

In fact, this is one aspect of Lutheran theology. The other aspect concerns a theology where God is becoming visible through Jesus Christ on the Cross. In this case, Martin Luther

\footnotetext{
${ }^{25}$ John Dillenberger, Hidden and Revealed. The interpretation of Luther's deus absconditus and its significance for religious thought, Muhleberg Press, Philadelphia, 1953.

${ }^{26}$ Oliver Davies and Denis Turner (eds), Silence and the Word. Negative Theology and Incarnation, Cambridge University Press, Cambridge, 2002; Arthur Bradley, Negative Theology and Modern French Philosophy, Routledge, London and New York, 2014 and Harold Coward and Toby Foshay (eds), Derrida and Negative Theology, State University of New York Press, Albany, 1992.

${ }^{27}$ Paul Rorem, The Dionysian Mystical Theology, Fortress Press, Minneapolis, 2015.

${ }^{28}$ Marius Timmann Mjaaland, The Hidden God. Luther, Philosophy, and Political Theology, Indiana University Press, Bloomington and Indianapolis, 2016, p. 91.

${ }^{29}$ Ernesto Laclau, Emancipation(s), Verso, London and New York, 1996, p. 36.

${ }^{30}$ Marius Timmann Mjaaland, The Hidden God. Luther, Philosophy, and Political Theology, Indiana University Press, Bloomington and Indianapolis, 2016, p. 91.

${ }^{31}$ Claude Lefort, Democracy and Political Theory, Polity Press, Cambridge, 1988, p. 17.

${ }^{32}$ Chantal Mouffe, The Democratic Paradox, Verso, London and New York, 2009.

33 Jacques Derrida, Rogues. Two Essays on Reason, Stanford University Press, Stanford, California, 2005 (Translated by Pascale-Anne Brault and Michael Naas), p. 78.
} 
builds the so-called Theology of Cross (theologia crucis) ${ }^{34}$. God's divine topos is the place of Cross. Hidden God is becoming visible on the Cross through or next to the suffering Christ. So, God is now present in-the-world as a Crucified and suffering $\operatorname{God}^{35}$. Now, the theological background comes straight from Apostle Paul and Pauline theology. It is worth noting that this critical turn in Lutheran theology is a bodily and political turn. Actually, we are a few steps away from modern political onto-theology. The specific and tangible body of Jesus Christ (and thus the hidden and mysterious 'body' of God) is transformed into the visible topos of the divine suffering on the Cross. The body of Jesus is conceived as the clear sign of God's invisibility. In poetic terms, the 'divine shirt' (or Jesus Christ's burial shroud; see also 'Tourine shroud'; or Sacra Sindone; or Sindone di Torino) has now a very specific body, i.e. the body of Christ (Corpus Christi) ${ }^{36}$.

Nevertheless, Theology of Cross must not be seen as an updated, so to speak, Pauline Christology. In fact, it must be considered more as a radical Political Christology ${ }^{37}$. The Platonic transcendence and the apophatic flavour of Dionysius the Areopagite are transformed into a political immanence. The new topos of political onto-theology is no longer this dark, strange, liquid and in the final analysis apocosmic (i.e. transcendental) Platonic Khôra, i.e. an outer land so far away from the human beings. In contrast, the new place of political onto-theology is the Platonic cave itself. If it is necessary to put some of the great figures of contemporary political onto-theology within this Lutheran double-faced theological context, it could be claimed that Martin Heidegger eventually forms a sort of apophatic or negative eschatological ontology (i.e. foundational ontology) ${ }^{38}$. Carl Schmitt finds himself somewhere in the middle of this theological continuum, since he actually builds a Christian-inspired political onto-theology in which deus absconditus is ultimately embodied into the modern Leviathan, i.e. the well-known Hobbesian State ${ }^{39}$. On the opposite side of this theological line is placed the case of New Political Theology of Jürgen Moltmann, where the political onto-theology is a pure theologia crucis; or a Political Christology; or a political

\footnotetext{
${ }^{34}$ Walter Von Loewenich, Luther's Theology of the Cross, Augsburg Publishing House, Minneapolis, 1976 (Translated by Herber J. A. Bouman); Alister E. McGrath, Luther's Theology of the Cross, Blackwell Publishers Ltd., Oxford, 2000; Daniel M. Deutschlander, The Theology of the Cross. Reflections on His Cross and Ours, Northwestern Publishing House, Milwaukee, WI, 2008 and Gerhard O. Forde, Theologian of the Cross. Reflections on Luther's Heidelberg Disputation, 1518, William B. Eerdmans Publishing Company, Grand Rapids, Michigan / Cambridge, U.K., 1997.

35 Jürgen Moltmann, The Crucified God. The Cross of Christ as the Foundation and Criticism of Christian Theology, Fortress Press, Minneapolis, MN, 1993 (Translated by R. A. Wilson and John Bowden).

${ }^{36}$ Henri Cardinal de Lubac SJ, Corpus Mysticum. The Eucharist and the Church in the Middle Ages, University of the Notre Dame Press, Notre Dame, Indiana, 2006 (Translated by Gemma Simmonds CJ with Richard Price and Christopher Stephens); Ernst H. Kantorowicz, The King's Two Bodies. A Study in Medieval Political Theology, Princeton University Press, Princeton, New Jersey, 2016 and Chris Boesel \& Catherine Keller (eds), Apophatic Bodies. Negative Theology, Incarnation, and Relationality, Fordham University Press, United States of America, 2010.

37 Raymund Schwager, "Christology", In: Peter Scott and William T. Cavanaugh (eds), The Blackell Companion to Political Theology, Blackwell Publishing, Oxford, 2005 (Translated by Karl Möller), pp. 348362.

38 Judith Wolfe, Heidegger and Theology, Bloomsbury, London, New Delhi, New York, Sydney, 2014 and Judith Wolfe, Heidegger's Eschatology. Theological Horizons in Martin Heidegger's Early Work, Oxford University Press, Oxford, 2015.

39 Michael Hollerich, "Carl Schmitt', In: Peter Scott and William T. Cavanaugh (eds), The Blackwell Companion to Political Theology, Blackwell Publishing, Oxford, 2005, pp. 107-122.
} 
onto-theology of immanent; where the visibility of human politics is represented by Corpus Christi $^{40}$.

Politically speaking, the two first versions of Lutheran onto-theology, both in the cases of Martin Heidegger and Carl Schmitt, led to a 'hard-line', so to speak, political ontotheology that brought to the fore either an onto-theological nihilism (where Martin Heidegger must be seen as a political idealist) ${ }^{41}$ or a strong state that historically during $20^{\text {th }}$ century approached the far limits of an authoritarian even totalitarian state (in this case Carl Schmitt must be considered as a pure political realist $)^{42}$. The other Lutheran side of political ontotheology leads to democracy in a twofold sense: either in the sense of the political ontotheology of Claude Lefort, where the empty place of power (or God, or King in the Middle Ages and during the era of Absolutism) is embodied, after the French Revolution, into the body (symbolically, a body without head: see Louis XVI) of democratic multitude ${ }^{43}$; or in the sense of New Political Theology of Jürgen Moltmann, where the modern political ontotheology is coming to the fore as a radical New Trinitarianism (see the traditional question of perichoresis $)^{44}$. In this regard, at the end of the day, this all-powerful and invisible deus absconditus is turned into a suffering God next to the poor and pariahs. This is nearly a socialist theology which has explicitly been affected by the postwar rise of Western Marxism, Critical Theory and the so-called New Social Movements ${ }^{45}$.

\section{THE DIDACTIC CASE OF NEW POLITICAL THEOLOGY}

Such as both politics and the political since Aristotle concern broadly the critical question of human collectivity and by extension the equally important issue of the optimum government in the same way Western theology constitutes a complex phenomenon that beyond the activities of catechesis and proselytism poses at the epicenter of liturgical life so many critical and thorny questions, as the question of human being itself, the question of the existence of God and His relation to the world, the question of social and political forms and the like ${ }^{46}$. Thereby, political theology, as an interdisciplinary subject, constitutes a major field, scrutinizing, analyzing and criticizing in-depth the political, psychological, social, moral and even economic illustrations or interpretations of the tripartite relationship amongst human beings, society and $\mathrm{God}^{47}$.

Although, the concept of theology and especially the notion of political theology preexist Christianity, to the extent that the first traces of political theology can be detected within the rich intellectual and experiential tradition of both Stoic philosophy and then

\footnotetext{
40 Alister E. McGrath, Historical Theology. An Introduction to the History of Christian Thought, WilleyBlackwell, Oxford, 1998, p. 195.

${ }^{41}$ Laurence Paul Hemming, Bogdan Costea, Kostas Amiridis (eds), The Movement of Nihilism. Heidegger's Thinking After Nietzsche, Bloomsbury, London, New Delhi, New York, Sydney, 2011.

42 Eckard Bolsinger, The Autonomy of the Political. Carl Schmitt and Lenin's Political Realism, Greenwood Press, Westport, Connecticut, London, 2001.

43 Claude Lefort, The Political Forms of Modern Society. Bureaucracy, Democracy, Totalitarianism, Polity Press, Cambridge, 1986, p. 292.

44 Nicholas Adams, “Jürgen Moltmann', In: Peter Scott and William T. Cavanaugh (eds), The Blackwell Companion to Political Theology, Blackwell Publishing, Oxford, 2005, pp. 227-240.

45 Jürgen Moltmann, “European Political Theology”, In: Craig Hovey, Elizabeth Phillips (eds), Christian Political Theology, Cambridge University Press, Cambridge, 2015, pp. 3-22.

46 Alister E. McGrath, Historical Theology. An Introduction to the History of Christian Thought, WilleyBlackwell, Oxford, 1998.

${ }^{47}$ Elizabeth Phillips, Political Theology. A Guide to the Perplexed, T \& T Clark, London and New York, 2012.
} 
ancient Rome, under the auspices of either the well-known mythical theology ${ }^{48}$ or the socalled natural theology ${ }^{49}$ or a sort of political theology that is associated with city gods in the sense of a civic religion ${ }^{50}$, political theology refers to Christianity and especially both to apostle Paul and the great Christian theologians after him (see Patristic Period c. 100-451) ${ }^{51}$. More specifically and although we talk about the Jewish political theology ${ }^{52}$ and also the Islamic political theology ${ }^{53}$, political theology is definitely concerned with the life above all the passion of Jesus Christ on the Cross. From this viewpoint, it is no coincidence that Christology consists of the hard core of the so-called New Political Theology ${ }^{54}$.

Since the 1960s, Carl Schmitt's political theology ceases to be the only way of understanding the entire theoretical project of contemporary political theology. The emergence of New Political Theology, chiefly through the oeuvre of German protestant theologian Jürgen Moltmann, has enriched further the intellectual approaches of Continental Philosophy. Political theology on the whole brings the crucial questions of both ontology and theology into a shiny light, creating an absolutely new and fresh philosophical and theoretical concern about politics and the political itself. Thus, in parallel, the postwar social and political theory is taking the character of a novel political onto-theology of public sphere, freedom and democracy as well. From this groundbreaking perspective, it is no accident that from Hannah Arendt ${ }^{55}$, Leo Strauss and Ernst Kantorowicz to Claude Lefort, Cornelius Castoriadis and Giorgio Agamben, to name only a few of them, contemporary political theory has been developed first and foremost as a systematic political onto-theology. It is noteworthy that at the heart of this new disciplinary development of contemporary political onto-theology is situated the famous Weimar Renaissance ${ }^{56}$. The political evilness of Nazism and by extension Totalitarianism posed the account of political onto-theology anew, as a strong necessity within the postwar historical and philosophical context. According to Theodor Adorno, Auschwitz has changed the conventional meaning of Western

${ }^{48}$ Edith Hamilton, Timeless Tales of Gods and Heroes ( $75^{\text {th }}$ Anniversary Edition), Black Dog \& Leventhal Publishers, New York, 2017.

49 William Lane Craig and J. P. Moreland (eds), The Blackwell Companion to Natural Theology, WileyBlackwell, Oxford, 2012.

50 John Scheid, An Introduction to Roman Religion, Indiana University Press, Bloomington \& Indianapolis, 2003 (Translated by Janet Lloyd).

51 Alister E. McGrath, Historical Theology. An Introduction to the History of Christian Thought, WilleyBlackwell, Oxford, 1998, p. 16.

52 Peter Ochs, “Abrahamic Theo-politics: A Jewish View', In: Peter Scott and William T. Cavanaugh (eds), The Blackwell Companion to Political Theology, Blackwell Publishing, Oxford, 2005, pp. 519-534.

${ }^{53}$ Bustami Mohamed Khir, "The Islamic Quest for Sociopolitical Justice', In: Peter Scott and William T. Cavanaugh (eds), The Blackwell Companion to Political Theology, Blackwell Publishing, Oxford, 2005, pp. 503-518.

54 Nicholas Adams, “Jürgen Moltmann', In: Peter Scott and William T. Cavanaugh (eds), The Blackwell Companion to Political Theology, Blackwell Publishing, Oxford, 2005, pp. 230-234.

55 John Kiess, Hannah Arendt and Theology, Bloomsbury, London, New Delhi, New York, Sydney, 2016.

${ }^{56}$ Leonard V. Kaplan, and Rudy Koshar (eds), The Weimar Moment. Liberalism, Political Theology, and Law, Lexington Books, Lanham, Boulder, New York, Toronto, Plymouth, UK, 2012; Graham Hammill \& Julia Reihard Lupton (eds), Political Theology and Early Modernity, The University of Chicago Press, Chicago and London, 2012, Andrew Gibson, Modernity and the Political Fix, Bloomsbury, London, New Delhi, New York, Sydney, 2019. 
Metaphysics $^{57}$. Therefore, by summarizing the sentiment after WWII, Hans Jonas speaks about the inevitable need to rethink the meaning of God after Auschwitz ${ }^{58}$.

The convergence between politics and theology has transformed into a strong condition within modernity, despite the fact that European Enlightenment tried hard to impose the image of secularization on the Western tradition. From Plato and St. Augustine until Jürgen Moltmann, the founder of the New Political Theology, passing through the Renaissance of the $12^{\text {th }}$ century in the late Middle Ages, when the theory about Corpus Christi was gradually turned into Corpus Mysticum and then into body politic, with both Christ and His vicar on earth King having two bodies, one mortal and the other immortal, symbolizing the eternity and continuation of political power itself, political onto-theology has become the dominant philosophical, theoretical and ethical condition of Modernity as a whole ${ }^{59}$. This ambivalent and risky movement of modernity towards a Promethean onto-theology is determined by Albert Camus as metaphysical rebellion ${ }^{60}$. In this new onto-theological image, Prometheus, Sisyphus and Jesus Christ call God Himself to put his back beneath the Cross. Golgotha is becoming the democratic fate of a Crucified God ${ }^{61}$. Since the French Revolution and up until today, the poor and pariahs of bourgeois democracy, as a new collective Prometheus, give political metaphysics a new and radical content ${ }^{62}$. Democratization of both politics and theology is coming to the fore as a strong onto-theological demand. The rise of Political Christology and particularly New Political Theology must be interpreted within this definitely new, liquid and radical historical context. In Derridean jargon, democracy is seen now as a messianic condition; as an aporia; as a theologia negativa; as an unfulfilled desire; or, in other words, as a democracy-to-come ${ }^{63}$. The unhealed trauma of Jesus on the Cross is becoming the unhealed trauma of democracy itself. If democracy is in the lasts analysis a theology without sovereignty then New Political Theology could be regarded as a democratic political theology ${ }^{64}$.

The revival of this fertile relationship between politics and theology in the $20^{\text {th }}$ century is taking place within the tragic context of WWI and WWII as well as the dramatic intermedium of interwar period. Weimar historical moment and Nazi's crimes against humanity put the basis for this new theological and political osmosis within the contemporary Western tradition. It is no coincidence that Jürgen Moltmann used to repeat as a monotonous refrain in most of his seminal books that New Political Theology must be perceived as the metonymy of Christian theology after Auschwitz ${ }^{65}$. In fact, New Political Theology reveals

\footnotetext{
57 Theodor Adorno, Metaphysics. Concepts and Problems, Polity Press, Cambridge, 2001 (Translated by Edmund Jephcott).

${ }^{58}$ Hans Jonas, Mortality and Morality: A Search for the Good after Auschwitz, Northwestern University Press, Evanston, Illinois, 1996, p. 131.

59 Ernst H. Kantorowicz, The King's Two Bodies. A Study in Medieval Political Theology, Princeton University Press, Princeton, New Jersey, 2016.

${ }^{60}$ Albert Camus, The Rebel, Penguin Books, London, 2000 (Translated by Anthony Bower), p. 29.

${ }^{61}$ Jürgen Moltmann, The Crucified God. The Cross of Christ as the Foundation and Criticism of Christian Theology, Fortress Press, Minneapolis, MN, 1993 (Translated by R. A. Wilson and John Bowden).

${ }^{62}$ Jeffrey W. Robbins, Radical Democracy and Political Theology, Columbia University Press, New York, 2011.

${ }^{63}$ John D. Caputo, The Prayers and Tears of Jacques Derrida. Religion Without Religion, Indiana University Press, Bloomington and Indianapolis, 1997.

${ }^{64}$ Jeffrey W. Robbins, Radical Democracy and Political Theology, Columbia University Press, New York, 2011, p. 174.

${ }^{65}$ Jürgen Moltmann, "European Political Theology", In: Craig Hovey, Elizabeth Phillips (eds), Christian Political Theology, Cambridge University Press, Cambridge, 2015, p. 1.
} 
the social and political significance of the constitutive question about the existence of God after Auschwitz. New Political Theology brings to light once more the problem of evil and the relevant problem of Theodicy. So, New Political Theology does not concern the Schmittean question of state sovereignty. New Political Theology was coined as a new term in order to draw a clear-cut distinction from the conventional meaning of the term as it was used by the famous German jurist and political thinker Carl Schmitt in the beginning of the Weimar era ${ }^{66}$. In the case of Schmitt, political theology concerns the theological justification of state sovereignty through a symbolical reading of Catholicism and Absolutism ${ }^{67}$. Without doubt, behind Schmittean political theology lies the view of Restoration and the image of a world where Christ and church give political power a sacred and transcendental character ${ }^{68}$. Contrary to this, New Political Theology does not refer to any form of politicization of theology. However, it does not refer to a sanctification of politics. Having as a starting point Jesus Christ himself and especially his passion on the Cross, it aims to the social and political activation of Christian theology against injustice, oppression, exploitation and poverty, situations that Jesus experienced over the course of his life. For Hannah Arendt, Jesus of Nazareth must be seen as a new Socrates, i.e. as the new archetype of conscious pariah ${ }^{69}$.

New Political Theology is born as a theology of hope for the pariahs of the postwar neo-capitalist world and by having this specific meaning, as Moltmann has pointed out so many times, it brings to the fore the importance of Karl Marx's thought, the significance of the heretical theology of the famous Franciscan Order, and above all the essential role of the Christian martyrology against all forms of despotism, tyranny and Totalitarianism ${ }^{70}$. Within the ranks of Christian martyrdom against Nazism, the figures of the German protestant theologian Dietrich Bonhoeffer, who was murdered by the Nazis ${ }^{71}$, and the Catholic St. Edith Stein, who was killed in Auschwitz ${ }^{72}$, stand out. Thereby, New Political Theology draws attention on the human and social liberation, as well as the emancipation of human beings against power and especially power in the form of hubris, arrogance and autocracy. It is no accident that Jürgen Moltmann determines New Political Theology as a form of self-criticism within the Christian church, through the expectancy of a Critical Theology ${ }^{73}$. Consequently, throughout the $20^{\text {th }}$ century, New Political Theology goes hand in hand, so to speak, with

\footnotetext{
${ }^{66}$ Carl Schmitt, Political Theology. Four Chapters on the Concept of Sovereignty, The University of Chicago Press, Chicago and London, 2012 (Translated by George Schwab) and Carl Schmitt, Political Theology II. The Myth of the Closure of any Political Theology, Polity Press, Cambridge, 2008 (Translated by Michael Hoelzl and Graham Ward).

${ }^{67}$ Carl Schmitt, Roman Catholicism and Political Form, Greenwood Press, Westport, Connecticut, London, 1996 (Translated by G. L. Ulmen).

${ }^{68}$ Carl Schmitt, Political Romanticism, The MIT Press, Cambridge, Massachusetts, and London, England, 1986 (Translated by Guy Oakes).

${ }^{69}$ Hannah Arendt, The Human Condition (Second Edition), The University of Chicago Press, Chicago, London, 1998, p. 238 and Hannah Arendt, The Jewish Writings, Schocken Books, New York, 2007, p. 275.

70 Jürgen Moltmann, Theology of Hope. On the Ground and the Implications of a Christian Eschatology, Fortress Press, Minneapolis, 1993 (Translated by James W. Leitch) and Jürgen Moltmann, The Way of Jesus Christ. Christology in Messianic Dimensions, SCM Press, London, 1999 (Translated by Margaret Kohl), pp. 196-212.

${ }^{71}$ John W. de Gruchy (ed.), The Cambridge Companion to Dietrich Bonhoeffer, Cambridge Univeristy Press, Cambridge, 2005.

${ }^{72}$ Mary Catharine Baseheart, S.C.N., Person in the World. Introduction to the Philosophy of Edith Stein, Springer-Science+Business Media, B.V., Dordrecht, 1997.

${ }_{73}$ Jürgen Moltmann, The Crucified God. The Cross of Christ as the Foundation and Criticism of Christian Theology, Fortress Press, Minneapolis, MN, 1993 (Translated by R. A. Wilson and John Bowden), p. 317.
} 
Continental Philosophy, Critical Theory and the so called New Social Movements, creating strong links with Contemporary Political Theory in a sense that sometimes it is difficult to distinguish the theologian from the political philosopher and so theology from political theory. From this standpoint, it is difficult to say with certainty whether Moltmann is a theologian or an eminent social and political philosopher or whether Giorgio Agamben is a political theorist or a famous representative of the contemporary political theology ${ }^{74}$.

The enlargement of political and theological field during the $20^{\text {th }}$ century, due to the tragic character of human history, brought once more the thorny issue of the presence of God in-the-world to the epicenter of public sphere. In fact, New Political Theology overturns the image of deus absconditus and by doing so challenges the theologian doctrine of divine apathy. Therefore, God appears to the world through the Crucified Christ or actually through the passion of Jesus on the Cross. Moltmann talks about a Crucified God who is entering into the world and by his presence on the Cross just next to His Son not only gets rid of the image of an apathetic divinity but, contrary to this perception, suffers next to the people as a primus inter pares. According to this new image of God, He turns out to be a fellow human; a fellow citizen; an equal among equals; or, in other words, a personification of the well-known human condition of Aristotelian political friendship. Thus, God by His presence on the Cross becomes a sufferer for the sake of people. New Political Theology apart from being a dynamic version of Christology constitutes an entirely radical ontological and moral question about the theological aspects of human life; of polis as such; or, by paraphrasing St. Augustine, as the question about City of God which exists next to Earthly City. Polis seems now a 'New Haven - New Earth'75.

Undoubtedly, the socio-political connotations of Moltmannian New Political Theology are revolutionary. It is no accident that in most of the cases it is defined as socialist theology. It is clear that since WWII, after the tragic aftermath of Auschwitz, in a world that faces new onto-theological issues under the dominance of neo-capitalism, Christian theology tries consciously and systematically to re-approach the human world through a new and fresh viewpoint. In this vein, the Second Vatican Council, which convoked by Pope John XXII on 11 October 1962 (1962-1965), the World Conference on Church and Society, that took place in Geneva in 1966, and the World Council of Churches, that was held in Uppsala in 1968, gave an image both of a new Christian theology and a new Christian Church that eagerly wanted to redefine their relationships with society and politics by using novel terms and fresh perspectives. Christian approach is no longer considered as a private topic or a conventional form of transcendence through pray. From then on, Christian theology is chiefly regarded as a matter of social solidarity, public interest, common good and awareness for the fellow human $^{76}$. For example, within the ranks of Catholic theology, characteristic are the cases of the French philosopher Jacques Maritain and the German Catholic theologian Johann-Baptist Metz, that opened up the field for the coming of New Political Theology as a political Christology where Jesus Christ is approached as the absolute ideal of common life and, as

\footnotetext{
${ }^{74}$ Giorgio Agamben, The Kingdom and the Glory. For a Theological Genealogy of Economy and Government, Stanford University Press, Stanford, California, 2011 (Translated by Lorenzo Chiesa with Matteo Mandarini).

${ }^{75}$ Jürgen Moltmann, The Coming of God. Christian Eschatology, SCM Press LTD, London, 1996 (Translated by Margaret Kohl), p. 257.

76 Jürgen Moltmann, Experiences in Theology. Ways and Forms of Christian Theology, SCM Press, London, 2000 (Translated by Margaret Kohl), pp. 183-289.
} 
Hannah Arendt says, as a clear instance of acting in concert $^{77}$. Gradually, New Political Theology has radically changed the content of the famous doctrine of the Trinity (i.e. One God, Three Persons). Now, interrelations between the three persons of God (i.e. the Father, Son and Holy Spirit) are no longer patriarchal but relations of brotherhood and/or sisterhood, fellowship and partnership ${ }^{78}$.

Especially in postwar Germany, within the context of denazification, Christian theology tried to rebuild its broken bonds with society. According to Hans Jonas, Western theology should re-defined its relationship with the phenomenon of God after Auschwitz, by putting in a public view the problem of evil, as well as the question of Theodicy: i.e. if the God is omnipotent, omnibenevolent and omniscient, then how does evil occurs (see unde malum: "what is the origin of the evil')? It is so interesting that within the framework of Jewish political theology, through the ontological principle of tzimtzum ${ }^{79}$, God exists only as a divine entity of non-domination. In pure Aristotelian terms, this is a republican God. To put it in a nutshell, this is a God, Who in order to be atoned before mankind after Auschwitz, makes room not only for the other Trinitarian persons, but for the people as a whole.

This new political and social condition within the Trinity draws its inspiration from Patristic theology and has defined as perichoresis (from Greek: ' $\pi \varepsilon \rho \imath \chi \omega ́ \rho \eta \sigma 1 \varsigma$ ', i.e. ' $\pi \varepsilon \rho \mathrm{s}$ '/around and ' $\chi \omega \rho \varepsilon i ́ v ' / m a k e$ room; in Latin: Circumincession) ${ }^{80}$. Perichoresis constitutes the defining element within Trinitarian theology of Jürgen Moltmann and also the eminent Greek Orthodox theologian John Zizioulas ${ }^{81}$. Actually, the image of God or more specifically, the condition of Triune God is turned into a condition of perichoresis. It is worth pointing out that political onto-theology of perichoresis is closely associated with the theology of Communio ${ }^{82}$. It is noteworty that Hans Urs von Balthasar and Henri de Lubac approach theodramatics through the liturgical action of the sacrament of Eucharist, where the Christian congregation is seen as a quasi-political community in the Aristotelian sense: i.e. political community as political friendship ${ }^{83}$. In this specific regard, theology of perichoresis transforms Christian onto-theology into a hermeneutics of common or apostolic life as was probably the daily life of proto-Christians in the era of Christian commons (in Greek: 'Kouvóß1o', i.e. common life). Then, in the far distant age of proto-Orthodox Christianity, the critical matter was not about leadership of Christians or monasteries but about common life and martyrdom.

\footnotetext{
77 Jacques Maritain, Scholasticism and Politics, Liberty Fund, Indianapolis, 2011 (Translated by Mortimer J. Adler); Johann-Baptist Metz and Jürgen Moltmann, Faith and the Future. Essays on Theology, Solidarity, and Modernity, SCM Press, London, 2012 and Hannah Arendt, The Human Condition (Second Edition), The University of Chicago Press, Chicago, London, 1998, p. 198 ("The polis [...] is the organization of the people as it arises out of acting and speaking together'").

${ }^{78}$ Jürgen Moltmann, Experiences in Theology. Ways and Forms of Christian Theology, SCM Press, London, 2000 (Translated by Margaret Kohl), pp. 303-343.

${ }^{79}$ Hans Jonas, Mortality and Morality: A Search for the Good after Auschwitz, Northwestern University Press, Evanston, Illinois, 1996, p. 131.

${ }^{80}$ Slobodan Stamatović, “The meaning of perichoresis", In: Open Theology, 2 (2016), pp. 303-323.

${ }^{81}$ Jürgen Moltmann, Experiences in Theology. Ways and Forms of Christian Theology, SCM Press, London, 2000 (Translated by Margaret Kohl), pp. 303-343 and John D. Zizioulas, The One and the Many. Studies on God, Man, the Church and the World Today, Sebastian Press, California, 2010.

82 John D. Zizioulas, Communion \& Otherness, T \& T Clark, London and New York, 2009, p. 286.

${ }^{83}$ Hans Urs von Balthasar, Theo-Drama. Theological Dramatic Theory. I: Prolegomena, Ignatius Press, San Francisco, 1988 (Translated by Graham Harrison).
} 
In Latin America, the convergence of Catholicism with Western Marxism in favor of pariahs of the continent, brought to the fore the so-called Liberation Theology ${ }^{84}$. In North America, within the broader context of the so-called New Social Movements (see for example women's movement; human rights movement; gay rights movement; peace movement; ecology movement etc.) Christian theology and political theory joined their forces against racism and sexism. Giving rise to a second generation of political theology, American political theology, under the auspices of the Public Theology, the Post-liberal Theology, the Radical Orthodoxy, the Feminist Theology, the Black Theology and the Queer Theology ${ }^{85}$, laid the basis for the academic recognition and the disciplinary autonomy of this specific field of thought and action which must be seen as New Political Theology on the whole. In our days, New Political Theology constitutes a structural and fertile source of contemporary social, political and ethical theory ${ }^{86}$.

\section{JÜRGEN MOLTMANN AND THE DIDACTIC CASE OF POLITICAL THEOLOGY OF THE CROSS}

Within the ranks of contemporary political onto-theology, dominant is the figure of the famous German protestant theologian Jürgen Moltmann. He defines political theology as new in the sense of a political theology that is entirely distinguished from Schmittian political theology. This new suggests that it has not the character of a new political ethics but that it is a political awakening of Western theology itself. As he clarifies further and further upon that, New Political Theology does not concern political systems. Also, he underlines that it does not concern a politics that takes a theological form but it means that Western theology adopts a new spiritual vehicle in order to re-establish itself in-the-world and for the love of the world (see the concept of amor mundi in Hannah Arendt: "the human world is always the product of man's amor mundi, a human artifice whose potential immortality is always subject to the mortality of those who build it and the natality of those who come to live in it'" $)^{87}$. Thereby, for Moltmann the point is not the politicization of Christian theology or the pietization (see piety) of politics. In contrast, New Political Theology pursues the re-start of Christian

${ }^{84}$ Gustavo Gutiérrez, A Theology of Liberation. History, Politics, and Salvation (15 ${ }^{\text {th }}$ Anniversary Edition), Orbis Books, New York (Translated by Sister Caridad Inda and John Eagleson).

${ }^{85}$ Elizabeth Phillips, Political Theology. A Guide to the Perplexed, T \& T Clark, London and New York, 2012, pp. $42-54$

${ }^{86}$ Dorothee Soelle, Political Theology, Fortress Press, Minneapolis, 1974; Paul Lakeland, Freedom in Christ. An Introduction to Political Theology, Fordham University Press, New York, 1986; John Howard Yoder, The Politics of Jesus, Wm. B. Eerdmans Publishing Co., Michigan, 1994; John Milbank, Theology \& Social Theory. Beyond Secular Reason, Blackwell Publishing, Oxford, 2006; Thia Cooper, Controversies in Political Theology, SCM Press, London, 2007; Michael Kirwan, Political Theology. A New Introduction, Darton, Longman \& Todd Ltd., London, 2008; Péter Losonczi and Aakash Singh (eds), From Political Theory to Political Theology. Religious Challenges and Prospects for Democracy, Continuum, London and New York, 2010; William T. Cavanaugh, Jeffrey W. Bailey, Graig Hovey (eds), An Eerdmans Reader in Contemporary Political Theology, Wm. B. Eerdmans Publishing Co., Michigan, 2012; Simon Critchley, The Faith of the Faithless. Experiments in Political Theology, Verso, London and New York, 2012; Clayton Crockett, Radical Political Theology, Columbia University Press, New York, Chichester, West Sussex, 2013; Francis Schüssler Fiorenza, Klaus Tanner, Michael Welker (eds), Political Theology. Contemporary Challenges and Future Directions, Westminster John Knox Press, Louisville, Kentucky, 2013; Michael Jon Kessler, Political Theology for a Plural Age, Oxford University Press, Oxford, 2013; Carl A. Raschke, Force of God. Political Theology and the Crisis of Liberal Democracy, Columbia University Press, West Sussex, 2015 and Péter Losonczi, Mika Luoma-Aho and Aakash Singh (eds), The Future of Political Theology. Religious and Theological Perspectives, Routledge, London and New York, 2016.

${ }^{87}$ Hannah Arendt, The Promise of Politics, Schocken Books, New York, 2005, p. 203. 
theology within public sphere for the sake of pariahs and poor people. A Christian theology worthy of the name, Moltmann claims, that is a theo-logy either as the logos of God (in

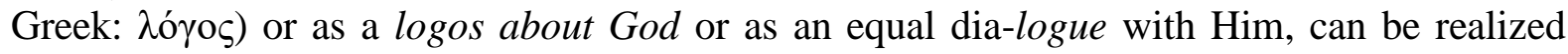
only when this dia-logue can take place within the onto-theological field of the political in the meaning of a field, as Karl Jaspers says, that concerns the human boundary situations* (*boundary situation is an immanent threshold that points to transcendence), i.e. both existence, suffering, struggle, guilt, fear, the knowledge of my death and the death of a loved one themselves ${ }^{88}$.

No doubt, New Political Theology, both activist and spiritual (see vita activa and vita contemplativa), tries to re-establish Spinozian or Straussian theologico-political problem in the heart of public space by deconstructing the individualistic (in the sense of egoistic) and mostly passive character of the traditional political onto-theology, either metaphysical or ethical $^{89}$. Like mythical Hercules, New Political Theology stands at the crossroads and from that ambivalent and boundary threshold scrutinizes in-depth the paradoxical possibilities between Christian messianic eschatology and the hard neo-capitalist reality ${ }^{90}$. Drawing its inspirations from a wide range background extended from biblical texts to contemporary Western theology, New Political Theology is formulated as a radical hermeneutical reflection about society and politics in late modernity ${ }^{91}$. From this specific point of view, new hermeneutics of political onto-theology is perceived not as a typical venture concerning the field of theological literature, but as a performative praxis that concerns the socio-political event itself $^{92}$. New Political Theology poses Christian theology in the epicenter of public life either as a Critical Theology or as a critical hermeneutics of neo-capitalism. For Moltmann, New Political Theology expresses the need for a new eschatological liberation of ordinary people in-the-world and for the sake of the world (amor Dei + amor mundi $=$ human liberation and emancipation $)^{93}$. Polis is identified now as the actual epicenter of this new post-metaphysical thought or political metaphysics. Therefore, human liberation is seen as a political phenomenon in the sense of an Aristotelian friendship. Trinity is no longer a patriarchal phenomenon but the actual expression of brotherhood and/or sisterhood. The 'God-Father' of traditional theology or Absolutism in political modernity or even a Descartes-driven psychoanalysis of an egoistic cogito is rejected for the sake of a republican and democratic Trinitarianism. This genre of deconstructive and performative analysis is defined by Moltmann as Trinitarian hermeneutics ${ }^{94}$.

\footnotetext{
${ }^{88}$ Karl Jaspers, Philosophy. Volume 2, The Univeristy of Chicago Press, Chicago and London, 1970 (Translated by E. B. Ashton), pp. 177-222.

${ }^{89}$ Leo Strauss, Spinoza's Critique of Religion, The Univeristy of Chicago Press, Chicago and London, 1997 (Translated by E. M. Sinclair) and Heinrich Meier, Leo Strauss and the Theologico-Political Problem, Cambridge Univeristy Press, Cambridge, 2007 (Translated by Marcus Brainard).

90 Jürgen Moltmann, The Way of Jesus Christ. Christology in Messianic Dimensions, SCM Press, London, 1999 (Translated by Margaret Kohl), pp. 73-150.

${ }^{91}$ Jürgen Moltmann, Experiences in Theology. Ways and Forms of Christian Theology, SCM Press, London, 2000 (Translated by Margaret Kohl), pp. 87-150.

92 Alain Badiou, Being and Event, Continuum, London and New York, 2007 (Translated by Oliver Feltham).

93 Jürgen Moltmann, The Coming of God. Christian Eschatology, SCM Press LTD, London, 1996 (Translated by Margaret Kohl), pp. 129-339.

94 Jürgen Moltmann, Experiences in Theology. Ways and Forms of Christian Theology, SCM Press, London, 2000 (Translated by Margaret Kohl), p. 134.
} 
Contrary to Schmittian political theology or according to approaches like this of Eric Voegelin, who analyzes the case of political religion ${ }^{95}$, Moltmannian theory rejects paganism where political religion concerns a state religion that is actually a system of power with religious connotations. As far as Moltmann is concerned, Jesus Christ, with his altruistic ethos and his tragic passion, strongly challenges the dominant image of a political religion during the Roman era by bringing to focus the radical case of a theologian approach that perceives community beyond dominance and sovereignty. In fact, New Political Theology demonstrates the republican and by extension democratic elements of Jesus's life, within which vita activa and vita contemplativa are articulated anew, in the sense of Aristotelian friendship. Jesus Christ was a primus inter pares amongst his disciples and he was appearing in the public sphere as a conscious pariah himself.

It is worth noting here that this kind of Christian political theology took place at the end of the interwar period within the work of the German theologian Erik Peterson. In his seminal book Monotheism as Political Problem ${ }^{96}$, Erik Peterson rejects Schmittian political theology where Monotheism is perceived actually as a theological monarchism. According to this approach, which is initially expressed in Carl Schmitt's famous treatise entitled Political Theology ${ }^{97}$, One and all-powerful God is equivalent to One and all-powerful Monarch. The whole universe is based on the absolutely strict logic One God-One Reason-One World. In fact, Christian theology turns into a theological justification of a global imperialism. In other words, Pax Romana signifies both realization and apotheosis of this monarchical approach of Christianity where One God corresponds to One Emperor to One Church to One Kingdom ${ }^{98}$.

According to New Political Theology, theological deconstruction of politicotheological Monotheism is taking place through the activation of the doctrine of the Trinity. Christianity is no longer the transformation of Pax Christi to Pax Romana. Christianity concerns first and foremost the revelation of Trinitarian community ${ }^{99}$. Christian God is no longer identified as Caesar and Power, but as Crucified God ${ }^{100}$. From this viewpoint, Christian faith is seen neither as a state religion, nor as a state ideology, but rather, as an ecumenical faith ${ }^{101}$. For Peterson, Christian theology cannot be a political theology. According to Moltmann, this is exactly the field on which New Political Theology rises. In the epicenter of New Political Theology, Moltmann places Jesus on the Cross. New Political Theology is taking place as a Theology of the Cross ${ }^{102}$. What is at stake here is not the power in the conventional sense, but the passion of Jesus on the Cross. It is no accident that Jesus Christ was crucified as an archetypal rebel against Pax Romana and every kind of power.

\footnotetext{
${ }^{95}$ Eric Voegelin, Modernity Without Restraint. Volume 5. The Political Religions; The New Science of Politics; And Science, Politics, And Gnosticism, University of Missouri Press, Columbia and London, 2000.

${ }^{96}$ Erik Peterson, Theological Tractates, Stanford University Press, Stanford, California, 2011.

${ }^{97}$ Carl Schmitt, Political Theology. Four Chapters on the Concept of Sovereignty, The University of Chicago Press, Chicago and London, 2012 (Translated by George Schwab).

98 Carl Schmitt, Political Theology II. The Myth of the Closure of any Political Theology, Polity Press, Cambridge, 2008 (Translated by Michael Hoelzl and Graham Ward).

99 Jürgen Moltmann, Experiences in Theology. Ways and Forms of Christian Theology, SCM Press, London, 2000 (Translated by Margaret Kohl), p. 328.

100 Jürgen Moltmann, The Crucified God. The Cross of Christ as the Foundation and Criticism of Christian Theology, Fortress Press, Minneapolis, MN, 1993 (Translated by R. A. Wilson and John Bowden), pp. 200-290.

101 Jürgen Moltmann, The Crucified God. The Cross of Christ as the Foundation and Criticism of Christian Theology, Fortress Press, Minneapolis, MN, 1993 (Translated by R. A. Wilson and John Bowden), pp. 7-31.

102 Jürgen Moltmann, The Crucified God. The Cross of Christ as the Foundation and Criticism of Christian Theology, Fortress Press, Minneapolis, MN, 1993 (Translated by R. A. Wilson and John Bowden), p. 65.
} 
Through Crucified Jesus, New Political Theology radically challenges all the established political and religious forms of power especially the so-called political and religious idols. It is no accident that Moltmann claims that as a theologia crucis, New Political Theology must be considered first and foremost as a theology of pariahs. Christian community is seen as a new Aristotelian polis, which is governed by the principles of love, equality and friendship. As Arendt points out, Aristotelian polis does not concern ó $\rho \chi \varepsilon l v$ (rule), but $\alpha \rho \chi \eta^{\prime}$, in the sense of Augustinian natality, i.e. either a new beginning or a new political foundation ${ }^{103}$. Cross is now the real emblem of this new Earthly city in which pariahs, the poor and the wretched, dominate without dominance (see Derrida's 'messianic without messianism') ${ }^{104}$. Just next to Jesus on the Cross appears God Himself as a Crucified God. This is the most critical moment of Theodramatics. Through Theology of Cross, Christian Trinity is transformed into a community of awareness, care, equality and solidarity. Following in Martin Luther's footsteps, who claims that the Cross is our only safe and true theology, Moltmann turns New Political Theology into a Critical Theology both for established Christian Church and secular power (see Gelasius's two swords theory) ${ }^{105}$.

As far as Moltmann is concerned, the historical and spiritual origins of New Political Theology must be detected in postwar Germany ${ }^{106}$. In fact, Auschwitz brought to focus both the problem of evil and Theodicy anew, sharply challenging the conventional wisdom regarding the theologico-political problem ${ }^{107}$. For Moltmann, Auschwitz has become the locus theologicus of postwar era. However, it is noteworthy that Auschwitz has not been put only as a turning point for the Western modernity itself (i.e. whatever Leo Strauss defines as crisis of modernity) ${ }^{108}$, but, at the same time, as a strong symptom of the crisis of Western theology as well as the Christian Church. Moltmann claims that the privatization of Christian faith led to the phenomenon of 'German Christians', which was actually the 'nazification' of one part of German Protestantism. This is because, in contrast, he provides the profile of Dietrich Bonhoeffer as the ideal model of a zealous Christian who moved from theological to political resistance. "His martyrdom", stresses Moltmann, "was a political martyrdom for Christ's sake"109. As Arendt with Jesus, he sees in the case of Dietrich Bonhoeffer a Christian who resists against absolute evil with passion and radicalness ${ }^{110}$. Thus, New Political Theology announces the total recall of Christian theology at the heart of public sphere, close to the poor and the pariahs of the polis, for the sake of justice, freedom, solidarity and peace.

\footnotetext{
${ }^{103}$ Hannah Arendt, The Promise of Politics, Schocken Books, New York, 2005, p. 91.

${ }^{104}$ Franz Fanon, The Wretched of the World, Grove Press, New York, 2004 (Translated by Richard Philcox) and Jacques Derrida, Spectres of Marx. The State of Debt, the Work of Mourning and the International, Routledge, New York and London, 2006 (Translated by Peggy Kamuf), p. 227.

105 Oliver O'Donovan and Joan Lockwood O'Donovan (eds), From Irenaeus to Grotius. A Sourcebook in Christian Political Thought 100-1625, William B. Eerdmans Publishing Company, Grand Rapids, Michigan / Cambridge, UK, 1999, p. 177.

106 Jürgen Moltmann, “European Political Theology”, In: Craig Hovey, Elizabeth Phillips (eds), Christian Political Theology, Cambridge University Press, Cambridge, 2015, pp. 8-14.

${ }^{107}$ Stanley Rosen, "Leo Strauss and the 'Theologico-Political Predicament", In: Steven B. Smith (ed.), The Cambridge Companion to Leo Strauss, Cambridge University Press, Cambridge, 2009, pp. 41-62.

${ }^{108}$ Liisi Keedus, The Crisis of German Historicism. The Early Political Thought of Hannah Arendt and Leo Strauss, Cambridge University Press, Cambridge, 2015.

109 Jürgen Moltmann, The Way of Jesus Christ. Christology in Messianic Dimensions, SCM Press, London, 1999 (Translated by Margaret Kohl), p. 201.

${ }^{110}$ Hannah Arendt, The Human Condition (Second Edition), The University of Chicago Press, Chicago, London, 1998, pp. 236-243.
} 
From the 1960s onwards, New Political Theology arises as a strong spiritual and practical need within radical ranks of postwar Western theology, both Catholic and Protestant. From the very beginning, it is in open communication with the most liberal groups of Critical Theory and Western Marxism. In this vein, Jürgen Moltmann strongly claims that New Political Theology represents the first clear sign of a post-Marxist theology, so to speak, where next to pariah-Jesus is coming to focus Marxist critique of the conservative and sometimes reactionary character of Christian religion. So, it is no accident that he draws his initial theological inspiration from the so-called messianic and eschatological Marxism that is articulated around the figure of Ernst Bloch and his seminal oeuvre on the principle of hope $(1938-1959)^{111}$. In fact, it could be claimed that New Political Theology is stemming from the deep intellectual trajectories of postwar Continental Philosophy as a Theology of Hope. Therefore, New Political Theology is not identified as a typical academic theology, but, in pure Marxian or Gramscian terms, as a theology of praxis; as a theology of social and political protest for the sake of pariahs in the neo-capitalist world.

Moltmann explicitly clarifies that is quite wrong for us to identify New Political Theology either with liberal Protestantism or moral Catholicism, meaning by that, either the case of the famous Catholic theologian and founder of New Political Theology Johann Baptist Metz or Catholic Social Ethics, or even other relevant political theologies as the case of Jacques Maritain. Contrary to liberal theologies that from a sociological standpoint must be perceived as theologies of middle classes, New Political Theology draws its inspiration from the evangelical origins of anti-establishment theology of Karl Barth, as well as the antiNazism resistance of the biggest part of German Protestantism, i.e. Confessing Church. As mentioned above, within the ranks of Confessing Church he distinguishes the figure of the contemporary martyr Dietrich Bonhoeffer who was killed by the Nazi both as a passionate Christian theologian and as a political rebel. It is apparent that New Political is coming to the fore as a sort of theology which resists any form of political violence and economic exploitation. By doing this, it pursues its revolutionary and redemptive principles within the biblical texts, especially the Gospels, putting special emphasis on the life and death of Jesus Christ. In this respect, it shares a lot with Christian Socialism. Thus, New Political Theology has a twofold character: on the one hand, it arises as a Critical Theology, i.e. a theological self-criticism within Christian Church. On the other hand, it has the character of a Western self-criticism, due to the fact of the profound crisis of capitalist modernity and Western neocolonialism (see Theology of Liberations) ${ }^{112}$. For example, Franz Fanon's political theology could be interpreted as a sort of a post-colonialist political theology ${ }^{113}$.

In addition, it is worth reminding that New Political Theology arises as a theoretical and experiential opponent against Carl Schmitt's political theology. For this concrete aim, Moltmann transforms New Political Theology from a theologia crucis into a democratized Trinitarian Theology. Moltmann's main goal is to bring to light the reactionary, antirevolutionary, anti-democratic and authoritarian character of Schmittian political theology.

\footnotetext{
111 Jürgen Moltmann, Theology of Hope. On the Ground and the Implications of a Christian Eschatology, Fortress Press, Minneapolis, 1993 (Translated by James W. Leitch); Jürgen Moltmann, Ethics of Hope, Fortress Press, Minneapolis, MN, 2012 (Translated by Margaret Kohl); Jacob Taubes, Occidental Eschatology, Stanford University Press, Stanford, California, 2009 (Translated by David Ratmoko), p. 164 and Ernst Bloch, The Principle of Hope, Volume One, Volume Two and Volume Three, The MIT Press, Cambridge, Massachusetts, 1986 (Translated by Neville Plaice, Stephen Plaice, \& Paul Knight).

112 Jürgen Moltmann, The Crucified God. The Cross of Christ as the Foundation and Criticism of Christian Theology, Fortress Press, Minneapolis, MN, 1993 (Translated by R. A. Wilson and John Bowden), pp. 335-338.

${ }^{113}$ Franz Fanon, The Wretched of the World, Grove Press, New York, 2004 (Translated by Richard Philcox).
} 
For Moltmann, Carl Schmitt chiefly tries to restore the monarchic spirit of European Absolutism. More specifically, he tries to show how theological monotheism turns into a political monarchism, by using either the Christian tradition of original sin or the Hobbesian political realism about the inherent evilness of human nature. In this Schmittian approach, both God and State constitute a Janus. So, Christ Himself, Christology and by extension Christianity are subjugated to the irresistible lure of state sovereignty ${ }^{114}$.

New Political Theology as Political Christology does not concern political power itself or public image of Leviathan, but aims to the awakening of Christian theology for the sake of the poor and the pariahs. As far as New Political Theology is concerned, Jesus Christ cannot be the ideal archetype either of Cesar or modern secular power. By doing this, New Political Theology radically changes the content and meaning of traditional political onto-theology. As we have seen above, this kind of non-monotheistic and non-monarchical political theology draws its basic inspirations from Patristic principle of perichoresis (or 'tzimtzum' according to the tradition of Jewish political theology $)^{115}$. In this regard, Christian Trinitarianism must not be perceived as a theological field in which God dominates as an authoritarian Father, but in contrary, it must be seen as a theological field that prevails the feeling of communal love or, in other words, a kind of community in which brotherhood and/or sisterhood predominates, instead of a social system with a vertical image of power.

According to the theological principle of perichoresis, Trinitarian life, that is society itself, is not based on the dominance of a single person (i.e. God or a political leader), but on the basis of a communal and fellow life where one person gives room to the other. From this point of view, Trinity is essentially transformed into a non-hierarchical community of equal persons, as the citizen-friends coexist in the Aristotelian polis. For New Political Theology, Trinity does not refer either to a divine self-consciousness (see Hegel) or a divine selfrevelation (see Karl Barth) or a divine self-communication (Karl Rahner), but to a form of coexistence and/or co-operation from below. The image of fellowship overturns the image of an omnipotent and omniscient God. Therefore, the model of social and political life changes radically. Instead of a God in the sense of a pater familias, we have now a communal life in the sense of brotherhood and/or sisterhood. According to Moltmann, political society is considered as a perichoretic society, where social relationship constitutes a kind of perichoresis or, in other words, a relationship where one gives plenty of room to the other ${ }^{116}$.

Individuality as well as the egoistic individualism of the Monarch is dissolved for the sake of communal life, fraternity and united equality of fellow citizens. Actually, faceless individual turns into a concrete person and political community is regarded as a congregation of thoughtful and responsible personalities. This is the actual meaning of Aristotelian

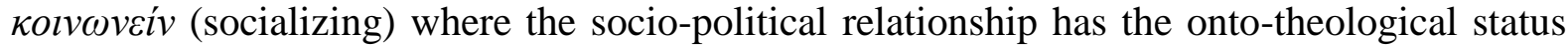
of an apophatic (see negative) event, i.e. socializing is something that is being understandable beyond the power of reason, just within the sphere of a miraculous and apocalyptic encounter with the Other (i.e. Jesus Christ or God Himself). In fact, the conventional state sovereignty is transformed into a perichoretic community. For Jürgen

\footnotetext{
${ }^{114}$ Carl Schmitt, Political Theology. Four Chapters on the Concept of Sovereignty, The University of Chicago Press, Chicago and London, 2012 (Translated by George Schwab) and Carl Schmitt, Political Theology II. The Myth of the Closure of any Political Theology, Polity Press, Cambridge, 2008 (Translated by Michael Hoelzl and Graham Ward).

115 Slobodan Stamatović, “The meaning of perichoresis”, In: Open Theology, 2 (2016), pp. 303-323.

116 Jürgen Moltmann, Experiences in Theology. Ways and Forms of Christian Theology, SCM Press, London, 2000 (Translated by Margaret Kohl), pp. 321-323.
} 
Moltmann, the ontological space of human existence is always common and interchangeable. Thus, egoistic possession and selfish ownership of power give their place to an unconditional and perpetual perichoresis to the Other; to our fellow citizens; to our brothers and sisters generally speaking ${ }^{117}$. God, through Jesus on the Cross, ceases to be an authoritarian Father (see Freudian or Lacanian notion about power as 'The-Name-of-the-Father') ${ }^{118}$ and so is perceived as a brother and/or a sister who gives us room in order we to co-exist. At the end of the day, New Political Theology is seen as a pure Ethical and Political Christology or, in other words, as a theory about political power as non-power; non-dominance; nonsovereignty; non-monarchical power; non-patriarchal power; by and large, as a nonhierarchical (so horizontal), communal and fraternal sort of anti-power.

This radical Political Christology of Communal Trinitarianism implies that New Political Theology is transformed from a typical theologia crucis to a revolutionary political Theology of the Cross. Fraternal God is seen as a co-suffering pariah on the Cross just next to Jesus Christ, for the sake of poor people. Crucified God, as a suffering metonymy of Jesus Christ on the Cross of martyrdom, constitutes the major symbol of New Political Theology. Community means suffer and co-suffer with and for my fraternity. Reminding Abraham Lincoln's famous saying about 'the government of the people, by the people, for the people', Moltmann asserts that this new political community signifies a new socio-political relationship where each human being lives with each Other and in each Other. To the extent that God Himself gets rid of His apathy, human being fills from sympathy for the fellow human. In order to reveal this new image of God, Moltmann brings to the fore the biblical image of Shekchina. Now, God Himself dwells in-the-world as a pariah-God. Monotheistic Trinitarianism gives room to perichoretic Trinitarianism. Political community is identified with social proximity. By formulating a pneumatological Trinitarianism á la Karl Barth, Moltmann leads us beyond Western modernity to a postmodern world, which is characterized by the integral unity of God and people. In Spinozian terms, maybe this new brave world is a pantheistic Trinitarianism. Since then, the job of human salvation does not belong to Popes or Monarchs but to the new political community of Shekchina. Trinity writes Moltmann "is our social programme",119.

\section{SOME CONCLUCIONS OR THE DIDACTIC CASE OF POST-FOUNDATIONAL POLITICAL ONTO-THEOLOGY}

The fruitful revival of political onto-theology in the $20^{\text {th }}$ century, just in the heart of the so-called Weimar Renaissance, is connected not only with the revised image of Middle Ages, but also with the total recall of the problem of evil in the epicenter of late modernity, due to the bloody and barbaric World Wars. Both New Political Theology, as well as postfundamental political onto-theologies in the sense of a radical onto-theologia negativa, brought to the forefront of contemporary social, political and ethical theory the essential issues of ontological, theological and moral interpretation of the political. It is no coincidence that New Political Theology comes to the postwar theoretical and experiential scene as a rival

\footnotetext{
${ }^{117}$ Spiros Makris, "Emmanuel Levinas on Hospitality. Ethical and Political Aspects”, In: International Journal of Theology, Philosophy and Science, Vol. 2, No. 2 (2018), pp. 79-96 and Spiros Makris, "Public sphere as 'ultimum refugium'. The philosophical, political and ethical theory of Hannah Arendt', In: International Journal of Theology, Philosophy and Science, Vol. 3, No. 4 (2019), pp. 77-92.

${ }^{118}$ Jacques Lacan, On the Names-of-the-Father, Polity Press, Cambridge, 2013 (Translated by Bruce Fink).

119 Jürgen Moltmann, The Crucified God. The Cross of Christ as the Foundation and Criticism of Christian Theology, Fortress Press, Minneapolis, MN, 1993 (Translated by R. A. Wilson and John Bowden), p. 332.
} 
against Schmittian political theology. Now, the focal point of analysis is not political power in the sense of state sovereignty, but a radical return to the forgotten theologian principles of Christology and Trinitarianism. As far as New Political Theology is concerned, the new content of political theology pursues more the republican and democratic aspects of a Crucified God on the Cross next to Jesus Christ, the poor and the pariahs. It is no coincidence that Moltmannian theology of hope is seen, in the final analysis, as a political theologia crucis. It is important to add that a significant role in the non-Schmittian political theology of the $20^{\text {th }}$ century is played by the messianic and/or apocalyptic Jewish political theology (see for example the political theology of Walter Benjamin) ${ }^{120}$, with apparent Marxist connotations and strong links with Critical Theory.

On the other hand, contemporary political onto-theologia, either as a ontologia negativa or as a theologia negativa, pursues beyond the conventional foundations of politics (i.e. Platonic Forms, God, King, State etc.) the creative power of Spinoza's conatus either as an abyssal foundation (see the Heidegger's Abgrund) or as a volcanic magma full of forms and meanings (see Castoriadis' social ontology about vis formandi). In this sense, political metaphysics is seen as a theoretical effort to interpret political societies in perpetuity. Thus, from Ernst Kantorowicz to Claude Lefort or from Leo Strauss and Walter Benjamin to Jürgen Moltmann and Giorgio Agamben, with the controversial figures of Heidegger and Schmitt to dominate the whole scene as the two theoretical pillars of both Weimar Renaissance and Continental philosophy, contemporary political onto-theologies have largely re-newed the content and the meanings of contemporary social, political and ethical theory. This enormous philosophical project, which tends to radically re-define ontological, theological and ethical borderlines of the political, seems like a frenetic leap to the chaos of democratic multitude, but without being entrapped in simplistic teleological or eschatological interpretations ${ }^{121}$.

Post-foundational character of contemporary social and political theory in the sense of a pure onto-theologia negativa actually indicates the opening-up towards a new kind of messianism and eschatology of the political itself. Contemporary political onto-theologies are considered more and more as a new post-metaphysical field, where politics is governed by the hard elements of fluidity, contingency and indeterminacy. The whole thing is defined by Jacques Derrida as a messianic without messianism or alternatively as a democracy to come. In its extreme version, this new onto-theological project of the political takes the radical form of anti-foundationalism where the theological element has been absorbed into the ontological one $^{122}$. This new desire for deus absconditus is moving now within the fields of a radical ontological, political and, in the last analysis, moral contingency and undecidability, where both Democracy and Totalitarianism are not regarded as two different political regimes, but as the two spectral poles across a continuum or a common onto-theological polarity. In fact, both Democracy and Totalitarianism are flowing unstoppably as interchangeable ontological and political spectralities on an onto-theological continuum, where politics is experienced as an absolutely risky phenomenon. According to Zygmunt Bauman, this is the human condition

\footnotetext{
${ }^{120}$ Walter Benjamin, Selected Writings, Volume 4, 1938-1940, Harvard University Press, U.S.A., 2016 and Walter Benjamin, Reflections. Essays, Aphorisms, Autobiographical Writings, Schocken Books, New York, 1978 (Translated by Edmund Jephcott), p. 277 and p. 312.

${ }^{121}$ Jeffrey W. Robbins, Radical Democracy and Political Theology, Columbia University Press, New York, 2011.

${ }^{122}$ Oliver Marchart, Post-Foundational Political Thought: Political Difference in Nancy, Lefort, Badiou and Laclau, Edinburgh University Press, Edinburgh, 2007 and Tomas Martila, Post-Foundational Discourse Analysis. From Political Difference to Empirical Research, Palgrave Macmillan, New York, 2015.
} 
of a liquid modernity or in the case of Nietzsche-inspired Jean Baudrillard, we live now in the era of the transparency of evil ${ }^{123}$.

In this perspective, while contemporary political onto-theologies illustrate the impasses of globalized neo-capitalism, at the same time, they demonstrate the profound and radical socio-political changes in the era of late modernity. This onto-theological ambiguity maybe indicates Moltmann's hope for some new opportunities concerning the Aristotelian principle of well-being (in Greek: $\varepsilon v \delta \alpha \_\mu v^{\prime} \alpha$ ). It is noteworty that etymologically speaking eudaemonia is a compound word which comes after 'eu' (meaning well) and 'daimon'

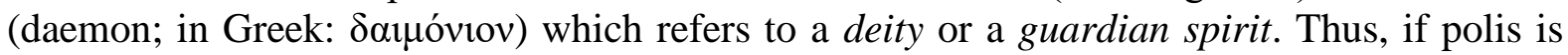
the realization of social and collectivity, that is something more than the typical political community, then political onto-theology concerns the deep origins of it or, to put it another way, this hidden deity (i.e. deus absconditus) that dwells in the basement of the political building. In mythological terms, political metaphysics is concerned with this ambiguous political monster or political Minotaur that is hiding beneath the city walls. It is worth noting that uncertainty, ambiguity and contingency of the political in the new ontological, theological and moral approaches do not lead towards a heterodox relativism. Instead, the condition of liquidity reestablishes the critical relationship between vita activa and vita contemplativa within the philosophical framework of a Socratic skepticism where the political depends both on human pluralism and alterity. In this specific area of ontotheological analysis, dominant is the figure of Hannah Arendt. Leading the movement of a postwar Aristotelian renaissance, she brings to light the onto-theological principles of personal responsibility and thoughtfulness as the backbone of thinking itself or what Heidegger defines as philosophizing in the Technological Age. If reflective thinking is the quintessence of political metaphysics then New Political Theology is a didactic case on how theologia crusis could be interpreted as a political Theology of the Cross.

\section{BIBLIOGRAPHY:}

[1] Alain Badiou, Being and Event, Continuum, London and New York, 2007 (Translated by Oliver Feltham).

[2] Albert Camus, The Rebel, Penguin Books, London, 2000 (Translated by Anthony Bower).

[3] Alister E. McGrath, Luther's Theology of the Cross, Blackwell Publishers Ltd., Oxford, 2000.

[4] Alister E. McGrath, Historical Theology. An Introduction to the History of Christian Thought, Willey-Blackwell, Oxford, 1998.

[5] Andrew Gibson, Modernity and the Political Fix, Bloomsbury, London, New Delhi, New York, Sydney, 2019.

[6] Arthur Bradley, Negative Theology and Modern French Philosophy, Routledge, London and New York, 2014.

[7] Benedict de Spinoza, Ethics, Penguin Books, London, 1996 (Translated by Edwin Curley).

[8] Bustami Mohamed Khir, "The Islamic Quest for Sociopolitical Justice”, In: Peter Scott and William T. Cavanaugh (eds), The Blackwell Companion to Political Theology, Blackwell Publishing, Oxford, 2005, pp. 503-518.

[9] Carl A. Raschke, Force of God. Political Theology and the Crisis of Liberal Democracy, Columbia University Press, West Sussex, 2015

[10] Carl Schmitt, Political Romanticism, The MIT Press, Cambridge, Massachusetts, and London, England, 1986 (Translated by Guy Oakes).

[11] Carl Schmitt, Roman Catholicism and Political Form, Greenwood Press, Westport, Connecticut, London, 1996 (Translated by G. L. Ulmen).

\footnotetext{
${ }^{123}$ Zygmunt Bauman, Liquid Modernity, Polity Press, Cambridge, 2000 and Spiros Makris, "Masses, Turbocapitalism and Power in Jean Baudrillard's Social and Political Ontotheology", In: International Journal of Theology, Philosophy and Science, Vol. 2, No. 3 (2018), pp. 91-112.
} 
[12] Carl Schmitt, Political Theology II. The Myth of the Closure of any Political Theology, Polity Press, Cambridge, 2008 (Translated by Michael Hoelzl and Graham Ward).

[13] Carl Schmitt, Political Theology. Four Chapters on the Concept of Sovereignty, The University of Chicago Press, Chicago and London, 2012 (Translated by George Schwab).

[14] Chantal Mouffe, The Democratic Paradox, Verso, London and New York, 2009.

[15] Chris Boesel \& Catherine Keller (eds), Apophatic Bodies. Negative Theology, Incarnation, and Relationality, Fordham University Press, United States of America, 2010.

[16] Claude Lefort, The Political Forms of Modern Society. Bureaucracy, Democracy, Totalitarianism, Polity Press, Cambridge, 1986.

[17] Claude Lefort, Democracy and Political Theory, Polity Press, Cambridge, 1988, p. 19 (Translated by David Macey).

[18] Clayton Crockett, Radical Political Theology, Columbia University Press, New York, Chichester, West Sussex, 2013.

[19] Daniel M. Deutschlander, The Theology of the Cross. Reflections on His Cross and Ours, Northwestern Publishing House, Milwaukee, WI, 2008.

[20] Dorothee Soelle, Political Theology, Fortress Press, Minneapolis, 1974.

[21] Eckard Bolsinger, The Autonomy of the Political. Carl Schmitt and Lenin's Political Realism, Greenwood Press, Westport, Connecticut, London, 2001.

[22] Edith Hamilton, Timeless Tales of Gods and Heroes ( $75^{\text {th }}$ Anniversary Edition), Black Dog \& Leventhal Publishers, New York, 2017.

[23] Elizabeth Phillips, Political Theology. A Guide to the Perplexed, T \& T Clark, London and New York, 2012.

[24] E. P. Sanders, Paul. The Apostle's Life, Letters and Thought, Fortress Press, U.S.A., 2015.

[25] Eric Voegelin, Modernity Without Restraint. Volume 5. The Political Religions; The New Science of Politics; And Science, Politics, And Gnosticism, University of Missouri Press, Columbia and London, 2000.

[26] Erik Peterson, Theological Tractates, Stanford University Press, Stanford, California, 2011.

[27] Ernst Bloch, The Principle of Hope, Volume One, Volume Two and Volume Three, The MIT Press, Cambridge, Massachusetts, 1986 (Translated by Neville Plaice, Stephen Plaice, \& Paul Knight).

[28] Ernst H. Kantorowicz, The King's Two Bodies. A Study in Medieval Political Theology, Princeton University Press, Princeton, New Jersey, 2016.

[29] Ernesto Laclau, Emancipation(s), Verso, London and New York, 1996.

[30] Francis Schüssler Fiorenza, Klaus Tanner, Michael Welker (eds), Political Theology. Contemporary Challenges and Future Directions, Westminster John Knox Press, Louisville, Kentucky, 2013.

[31] Franz Fanon, The Wretched of the World, Grove Press, New York, 2004 (Translated by Richard Philcox).

[32] Frank Schalow and Alfred Denker, Historical Dictionary of Heidegger's Philosophy (Second Edition), The Scarecrow Press, Inc., Lanham, Toronto, Plymouth, UK, 2010.

[33] Gerhard O. Forde, Theologian of the Cross. Reflections on Luther's Heidelberg Disputation, 1518, William B. Eerdmans Publishing Company, Grand Rapids, Michigan / Cambridge, U.K., 1997.

[34] Giorgio Agamben, The Kingdom and the Glory. For a Theological Genealogy of Economy and Government, Stanford University Press, Stanford, California, 2011 (Translated by Lorenzo Chiesa with Matteo Mandarini).

[35] Graham Hammill \& Julia Reihard Lupton (eds), Political Theology and Early Modernity, The University of Chicago Press, Chicago and London, 2012.

[36] Gustavo Gutiérrez, A Theology of Liberation. History, Politics, and Salvation (15 ${ }^{\text {th }}$ Anniversary Edition), Orbis Books, New York (Translated by Sister Caridad Inda and John Eagleson).

[37] Hannah Arendt, The Human Condition (Second Edition), The University of Chicago Press, Chicago, London, 1998.

[38] Hannah Arendt, The Promise of Politics, Schocken Books, New York, 2005.

[39] Hannah Arendt, The Jewish Writings, Schocken Books, New York, 2007.

[40] Hans Jonas, Mortality and Morality: A Search for the Good after Auschwitz, Northwestern University Press, Evanston, Illinois, 1996.

[41] Hans Urs von Balthasar, Theo-Drama. Theological Dramatic Theory. I: Prolegomena, Ignatius Press, San Francisco, 1988 (Translated by Graham Harrison).

[42] Harold Coward and Toby Foshay (eds), Derrida and Negative Theology, State University of New York Press, Albany, 1992. 
[43] Heinrich Meier, Leo Strauss and the Theologico-Political Problem, Cambridge Univeristy Press, Cambridge, 2007 (Translated by Marcus Brainard).

[44] Henri Cardinal de Lubac SJ, Corpus Mysticum. The Eucharist and the Church in the Middle Ages, University of the Notre Dame Press, Notre Dame, Indiana, 2006 (Translated by Gemma Simmonds CJ with Richard Price and Christopher Stephens).

[45] Jacob Taubes, The Political Theology of Paul, Stanford University Press, Stanford, California, 2004 (Translated by Dana Hollander).

[46] Jacob Taubes, Occidental Eschatology, Stanford University Press, Stanford, California, 2009 (Translated by David Ratmoko).

[47] Jacques Derrida, On the Name, Stanford University Press, Stanford, California, 1995 (Translated by David Wood, John B. Leavey, Jr., and Ian McLeod).

[48] Jacques Derrida, Rogues. Two Essays on Reason, Stanford University Press, Stanford, California, 2005 (Translated by Pascale-Anne Brault and Michael Naas).

[49] Jacques Derrida, Spectres of Marx. The State of Debt, the Work of Mourning and the International, Routledge, New York and London, 2006 (Translated by Peggy Kamuf).

[50] Jacques Lacan, On the Names-of-the-Father, Polity Press, Cambridge, 2013 (Translated by Bruce Fink).

[51] Jacques Maritain, Scholasticism and Politics, Liberty Fund, Indianapolis, 2011 (Translated by Mortimer J. Adler).

[52] J. B. Phillips, The New Testament in New English (Revised Edition), Touchstone Book, New York, 1995.

[53] Jeffrey W. Robbins, Radical Democracy and Political Theology, Columbia University Press, New York, 2011.

[54] Johann-Baptist Metz and Jürgen Moltmann, Faith and the Future. Essays on Theology, Solidarity, and Modernity, SCM Press, London, 2012.

[55] John D. Caputo, Radical Hermeneutics, Indiana University Press, Bloomington and Indianapolis, 1987.

[56] John D. Caputo, The Prayers and Tears of Jacques Derrida. Religion Without Religion, Indiana University Press, Bloomington and Indianapolis, 1997.

[57] John D. Zizioulas, Communion \& Otherness, T \& T Clark, London and New York, 2009.

[58] John D. Zizioulas, The One and the Many. Studies on God, Man, the Church and the World Today, Sebastian Press, California, 2010.

[59] John Dillenberger, Hidden and Revealed. The interpretation of Luther's deus absconditus and its significance for religious thought, Muhleberg Press, Philadelphia, 1953.

[60] John Howard Yoder, The Politics of Jesus, Wm. B. Eerdmans Publishing Co., Michigan, 1994.

[61] John Kiess, Hannah Arendt and Theology, Bloomsbury, London, New Delhi, New York, Sydney, 2016.

[62] John Milbank, Theology \& Social Theory. Beyond Secular Reason, Blackwell Publishing, Oxford, 2006.

[63] John Scheid, An Introduction to Roman Religion, Indiana University Press, Bloomington \& Indianapolis, 2003 (Translated by Janet Lloyd).

[64] John W. de Gruchy (ed.), The Cambridge Companion to Dietrich Bonhoeffer, Cambridge Univeristy Press, Cambridge, 2005.

[65] Judith Wolfe, Heidegger and Theology, Bloomsbury, London, New Delhi, New York, Sydney, 2014.

[66] Judith Wolfe, Heidegger's Eschatology. Theological Horizons in Martin Heidegger's Early Work, Oxford University Press, Oxford, 2015.

[67] Jürgen Moltmann, The Crucified God. The Cross of Christ as the Foundation and Criticism of Christian Theology, Fortress Press, Minneapolis, MN, 1993 (Translated by R. A. Wilson and John Bowden).

[68] Jürgen Moltmann, Theology of Hope. On the Ground and the Implications of a Christian Eschatology, Fortress Press, Minneapolis, 1993 (Translated by James W. Leitch).

[69] Jürgen Moltmann, The Coming of God. Christian Eschatology, SCM Press LTD, London, 1996 (Translated by Margaret Kohl).

[70] Jürgen Moltmann, The Way of Jesus Christ. Christology in Messianic Dimensions, SCM Press, London, 1999 (Translated by Margaret Kohl). 
[71] Jürgen Moltmann, Experiences in Theology. Ways and Forms of Christian Theology, SCM Press, London, 2000 (Translated by Margaret Kohl).

[72] Jürgen Moltmann, Ethics of Hope, Fortress Press, Minneapolis, MN, 2012 (Translated by Margaret Kohl).

[73] Jürgen Moltmann, "European Political Theology”, In: Craig Hovey, Elizabeth Phillips (eds), Christian Political Theology, Cambridge University Press, Cambridge, 2015.

[74] Immanuel Kant, Religion within the Boundaries of Mere Reason and Other Writings, Cambridge University Press, Cambridge, 2018 (Translated by Allen Wood).

[75] Karl Jaspers, Philosophy. Volume 2, The Univeristy of Chicago Press, Chicago and London, 1970 (Translated by E. B. Ashton).

[76] Laurence Paul Hemming, Bogdan Costea, Kostas Amiridis (eds), The Movement of Nihilism. Heidegger's Thinking After Nietzsche, Bloomsbury, London, New Delhi, New York, Sydney, 2011.

[77] Leonard V. Kaplan, and Rudy Koshar (eds), The Weimar Moment. Liberalism, Political Theology, and Law, Lexington Books, Lanham, Boulder, New York, Toronto, Plymouth, UK, 2012.

[78] Leo Strauss, Spinoza's Critique of Religion, The Univeristy of Chicago Press, Chicago and London, 1997 (Translated by E. M. Sinclair).

[79] Liisi Keedus, The Crisis of German Historicism. The Early Political Thought of Hannah Arendt and Leo Strauss, Cambridge University Press, Cambridge, 2015.

[80] Marius Timmann Mjaaland, The Hidden God. Luther, Philosophy, and Political Theology, Indiana University Press, Bloomington and Indianapolis, 2016.

[81] Mary Catharine Baseheart, S.C.N., Person in the World. Introduction to the Philosophy of Edith Stein, Springer-Science+Business Media, B.V., Dordrecht, 1997.

[82] Michael Jon Kessler, Political Theology for a Plural Age, Oxford University Press, Oxford, 2013.

[83] Michael Kirwan, Political Theology. A New Introduction, Darton, Longman \& Todd Ltd., London, 2008.

[84] Nicholas Adams, “Jürgen Moltmann', In: Peter Scott and William T. Cavanaugh (eds), The Blackwell Companion to Political Theology, Blackwell Publishing, Oxford, 2005, pp. 227-240.

[85] Oliver Davies and Denis Turner (eds), Silence and the Word. Negative Theology and Incarnation, Cambridge University Press, Cambridge, 2002.

[86] Oliver Marchart, Post-Foundational Political Thought: Political Difference in Nancy, Lefort, Badiou and Laclau, Edinburgh University Press, Edinburgh, 2007.

[87] Oliver O’Donovan and Joan Lockwood O'Donovan (eds), From Irenaeus to Grotius. A Sourcebook in Christian Political Thought 100-1625, William B. Eerdmans Publishing Company, Grand Rapids, Michigan / Cambridge, UK, 1999.

[88] Paul Lakeland, Freedom in Christ. An Introduction to Political Theology, Fordham University Press, New York, 1986.

[89] Paul Rorem, The Dionysian Mystical Theology, Fortress Press, Minneapolis, 2015.

[90] Péter Losonczi and Aakash Singh (eds), From Political Theory to Political Theology. Religious Challenges and Prospects for Democracy, Continuum, London and New York, 2010.

[91] Péter Losonczi, Mika Luoma-Aho and Aakash Singh (eds), The Future of Political Theology. Religious and Theological Perspectives, Routledge, London and New York, 2016.

[92] Peter Ochs, “Abrahamic Theo-politics: A Jewish View”, In: Peter Scott and William T. Cavanaugh (eds), The Blackwell Companion to Political Theology, Blackwell Publishing, Oxford, 2005, pp. 519534.

[93] Plato, Republic, Dover Thrift Editions, United States, 2000 (Translated by Benjamin Jowett).

[94] Plato, Five Dialogues, Hackett Publishing Company, Inc., United States of America, 2002 (Translated by G. M. A. Grube).

[95] Raymund Schwager, “Christology”, In: Peter Scott and William T. Cavanaugh (eds), The Blackell Companion to Political Theology, Blackwell Publishing, Oxford, 2005 (Translated by Karl Möller).

[96] Richard E. Palmer, Hermeneutics. Interpretation Theory in Schleiermacher, Dilthey, Heidegger, and Gadamer, Northwestern University Press, Evanston, 1969.

[97] Saint Augustine, City of God, Random House, Inc., New York, 1958.

[98] Sigmund Freud, The Uncanny, Penguin Books, London, 2003 (Translated by David McLintock).

[99] Simon Critchley, The Faith of the Faithless. Experiments in Political Theology, Verso, London and

New York, 2012.

[100] Simon Morgan Wortham, The Derrida Dictionary, Continuum, London and New York, 2010.

[101] Slobodan Stamatović, “The meaning of perichoresis”, In: Open Theology, 2 (2016), pp. 303-323. 
[102] Spiros Makris, “Aristotle in Hannah Arendt's Republicanism. From homo faber to homo politicus", In: Annuaire International Des Droits De L' Homme, Volume IX, 2015-2016, Issy-lesMoulineaux Cedex, Paris: L.G.D.J. lextensoéditions (2017), pp. 535-563.

[103] Spiros Makris, 'Democracy as a 'form of society'. Claude Lefort's post-foundational approach', In: 13th Conference of the European Sociological Association. (Un)Making Europe: Capitalism, Solidarities, Subjectivities. ESA 2017 Athens 29. 08 - 01. 09. Abstract Book, European Sociological Association, Hellenic Sociological Society, European Sociological Association, Paris, 2017.

[104] Spiros Makris, "Emmanuel Levinas on Hospitality. Ethical and Political Aspects", In: International Journal of Theology, Philosophy and Science, Vol. 2, No. 2 (2018), pp. 79-96.

[105] Spiros Makris, “Masses, Turbo-capitalism and Power in Jean Baudrillard's Social and Political Ontotheology', In: International Journal of Theology, Philosophy and Science, Vol. 2, No. 3 (2018), pp. 91-112.

[106] Spiros Makris, “Public sphere as 'ultimum refugium'. The philosophical, political and ethical theory of Hannah Arendt', In: International Journal of Theology, Philosophy and Science, Vol. 3, No. 4 (2019), pp. 77-92.

[107] Stanley Rosen, "Leo Strauss and the 'Theologico-Political Predicament",, In: Steven B. Smith (ed.), The Cambridge Companion to Leo Strauss, Cambridge University Press, Cambridge, 2009.

[108] Suzi Adams, Castoriadis's Ontology. Being and Creation, Fordham University Press, New York, 2011.

[109] Theodor Adorno, Metaphysics. Concepts and Problems, Polity Press, Cambridge, 2001 (Translated by Edmund Jephcott).

[110] Thia Cooper, Controversies in Political Theology, SCM Press, London, 2007.

[111] Tomas Martila, Post-Foundational Discourse Analysis. From Political Difference to Empirical Research, Palgrave Macmillan, New York, 2015.

[112] Walter Benjamin, Reflections. Essays, Aphorisms, Autobiographical Writings, Schocken Books, New York, 1978 (Translated by Edmund Jephcott).

[113] Walter Benjamin, Selected Writings, Volume 4, 1938-1940, Harvard University Press, U.S.A., 2016.

[114] Walter Von Loewenich, Luther's Theology of the Cross, Augsburg Publishing House, Minneapolis, 1976 (Translated by Herber J. A. Bouman).

[115] William Lane Craig and J. P. Moreland (eds), The Blackwell Companion to Natural Theology, Wiley-Blackwell, Oxford, 2012.

[116] William Shakespeare, Hamlet, Simon \& Schuster Paperbacks, New York, 2012.

[117] William T. Cavanaugh, Jeffrey W. Bailey, Graig Hovey (eds), An Eerdmans Reader in Contemporary Political Theology, Wm. B. Eerdmans Publishing Co., Michigan, 2012.

[118] Zygmunt Bauman, Liquid Modernity, Polity Press, Cambridge, 2000. 